is not only to describe the general principles of direct methods but also, and perhaps more important, the techniques for their practical application. The book presupposes a sound knowledge of the fundamentals of X-ray crystallography, so that it cannot be recommended to a newcomer in the field. But, within its chosen limits, it succeeds admirably, as might have been expected from its author, who has himself made important contributions to the field. Many of the methods are illustrated by the solution of an actual structure, and examples (with solutions) are provided for the reader to try himself. The mathematical requirements are wisely kept to a minimum and derivations collected in appendixes. In the final chapter the author gives an assessment of the power of direct methods and attempts to set rough limits to the complexity of erystal structures which might be solved by their use. They rival other methods in general efficacy and are already a valuable addition to the armoury of erystallographers. With the increasing general availability of fast electronic computers, their importance is almost bound to grow, and this book helps to point the way.

A. KrUG:

\section{BROADCASTING IN BRITAIN}

\section{British Broadcasting in Transition}

By Dr. Burton Paulu. Pp. vi+250. (London: Macmillan and Co., Ltd.; Minneapolis: University of Minnesota Press, 1961.) 35s. net.

$P^{\mathrm{R}}$ ROF. PAULU'S new book is described as a sequel to his earlier book British Broadcasting: Radio and Television in the United Kingdom, published in 1956, but the extent of the repetition from that earlier book makes the appropriateness of the term 'sequel' a motter of opinion. It can fairly be described as a work complete in itself which surveys fairly objectively the present situation of British broadcasting and the developments since 1955. He writes primarily to interpret this scene to the American reader, but he appraises the achievements both of the British Broadcasting Corporation, of which he has unreserved admiration, and of the Independent Television Authority. He believes that British television has been improved by competition, but that competition for British broadcasting has been good only because the Television Act of 1954 set up a system of controlled commercial television with conditions favourable to the regulating agency. The B.B.C., nevertheless, should be maintained and strengthened in its present basis, and sound broadcasting should continue as a B.B.C. monopoly. If funds are available both the B.B.C. and the Independent Television Authority should be encouraged to introduce additional television services, and responsibility for any additional commercial services should be assigned to the latter rather than to a second commercial authority.

On the technical side, on which Dr. Paulu appends a. note on television technical data, he recommends that the United Kingdom should adopt the recommendation of the Television Advisory Committee and replace its present 405 -line with a 625 -line system, at the same time expanding into V.H.F. Band IV and V. At a meeting of the Parliamentary and Scientific Committee last May, Sir Harold Bishop, Mr. A. L. Sutherland and Mr. D. W. Heightman all supported this recommendation of the Committee, and Prof. Paulu's technical note should be read in the light of that discussion and the evidence already submitted to the Pilkington Committee. By and large, however, he has given us a more useful as well as more up-to-date summary of the situation than is contained in his earlier book, and with a comprehensive bibliography it brings together in one volume the essential information for informed discussion of a vital subject. For the British reader in particular it, is apt to be heavy going but the author's comments and reservations, for example, about the Third Programme and educational broadcasting are suggestive, and where they do not put the essential questions themselves could well stimulate them. R. BRIGHTMAN

\section{BUSINESS ORGANIZATION AND MANAGEMENT}

\section{Studies in Business Organisation}

Edited by Prof. Ronald S. Edwards and Harry Townsend. (A Supplement to "Business Enterprise".) Pp. xxiii + 160. (London: Macmillan and Co., Ltd.; New York: St. Martin's Press, Inc., 1961.) 25s. net. $\mathrm{N}$ this book eight leading business men, the
Administrator of the Royal Opera House, Covent Garden, and the Controller of H.M. Stationery Office, write about the undertakings in which they are actively engaged.

Each of these papers has been presented at one of Prof. Edward's Tuesday evening seminars at the London School of Economics, and any of the many people who have attended those seminars will testify to the frankness with which organization problems of large concerns have been described and discussed at. them.

It is a far cry from the manufacture and sale of bolts, nuts and screws to the administration of an opera house or the organization of a Government department, and the variety described in these papers is therefore considerable and is fascinating. In an earlier book, Business Enterprise (1958), the authors discussed various features of industrial organization, and the present book provides material which amplifies or qualifies that discussion.

In an introduction the authors discuss briefly the contents of the book, and come to the conclusion that there are no universal prescriptions for organization. They point out that to some extent organization grows out of outdated decisions, tends to cope with new situations, and, to some extent, it represents deliberate adjustment to existing conditions. They conclude that as historical and business conditions both differ for different firms, the resultant forms of organization are bound to differ.

When looking at the organization of firms and institutions, I have often wondered whether the form of organization which has developed in them owes more to the purpose to be served or to the personality and outlook of the principal people concerned. Sometimes it seems to me to be one, sometimes the other, but my general impression is that the strength of character and personality of the 'boss' is, on the whole, the dominant factor determining the type of organization. This seems to be borne out by Sir George Dowty's statement that: "I have found that money in any business is not the first requirement -good ideas are by far the most important com. modity".
E. S. Hiscocks 